\title{
MENINGKATKAN KEMAMPUAN BERPIKIR KRITIS DAN KREATIF MATEMATIK DENGAN PENDEKATAN MODEL ELICITING ACTIVITIES (MEAs) PADA SISWA SMA
}

Oleh:

\author{
Euis Istianah
}

Guru SMA Negeri 23 Bandung

\begin{abstract}
Kemampuan berpikir siswa, baik berpikir kritis maupun berpikir kreatif merupakan kemampuan yang penting untuk dimiliki agar dapat memecahkan persoalan-persoalan yang dihadapi dalam dunia yang senantiasa berubah. Pembelajaran matematika dengan pendekatan Model-Eliciting Activities (MEAs) merupakan suatu alternatif pendekatan yang berupaya meningkatkan kemampuan berpikir kritis dan kreatif matematik siswa agar terus terlatih dengan baik. Penelitian ini bertujuan untuk menelaah peningkatan kemampuan berpikir kritis dan kreatif matematik antara siswa yang memperoleh pembelajaran matematika dengan pendekatan MEAs dan siswa yang memperoleh pembelajaran dengan pembelajaran biasa baik ditinjau secara keseluruhan maupun ditinjau secara kelompok siswa (kelompok atas dan kelompok bawah). Selain itu diungkap pula sikap siswa terhadap pembelajaran matematika dengan pendekatan MEAs. Desain penelitian ini adalah pre-test post-test control group design. Penelitian ini dilakukan di SMA pada level menengah. Data penelitian dikumpulkan melalui tes dan angket. Analisis data dilakukan terhadap rerata gain ternormalisasi antara kedua kelompok sampel dengan menggunakan kesamaan dua rerata. Hasil penelitian menunjukkan bahwa peningkatan kemampuan berpikir kreatif matematik siswa yang belajar dengan pendekatan MEAs lebih baik secara signifikan daripada siswa yang belajar dengan pembelajaran biasa, dan peningkatan kemampuan berpikir kritis matematik siswa yang belajar dengan pembelajaran biasa secara signifikan lebih baik daripada siswa yang belajar dengan pendekatan MEAs. Selanjutnya peningkatan kemampuan berpikir kreatif matematik siswa baik kelompok atas maupun kelompok bawah yang memperoleh pembelajaran matematika dengan pendekatan MEAs lebih baik secara signifikan daripada siswa kelompok atas dan kelompok bawah yang mendapatkan pembelajaran biasa, dan peningkatan kemampuan berpikir kritis matematik siswa baik kelompok atas maupun kelompok bawah yang belajar dengan pembelajaran biasa lebih baik secara signifikan daripada siswa kelompok atas dan kelompok bawah yang belajar dengan pendekatan MEAs. Selanjutnya analisis data angket sikap siswa memperlihatkan bahwa siswa menunjukan sikap positif terhadap pembelajaran matematika dengan pendekatan MEAs.
\end{abstract}

Kata Kunci : kemampuan berpikir kritis dan kreatif matematik, pendekatan Model Eliciting Activities (MEAs)

Students' thinking skills, both critical thinking and creative thinking is an important ability to have in order to solve the problems faced in a changing world . Mathematics learning approach to model - eliciting Activities ( MEAs ) is an alternative approach that seeks to 
improve the ability to think critically and creatively mathematics students to continue well trained. This study aims to examine the increase in critical and creative thinking skills among students receiving mathematics learning mathematics with MEAs and approach learning with students receiving regular lessons well reviewed as a whole and viewed in a group of students ( groups above and below the group ). In addition revealed the attitude of students towards learning mathematics with MEAs approach. The study design was a pre test post-test control group design. The research was conducted at the high school at midlevel . Data were collected through tests and questionnaires . Data analysis was conducted on the mean normalized gain between the two groups of samples using the similarity of the two averages. The results showed that an increase in the ability of creative thinking of students who are learning mathematics with MEAs approach is significantly better than students who studied the regular learning, and enhancement of critical thinking skills that students learn mathematics with common learning is significantly better than students who learn to approach MEAs . Further increase students ' ability to think creatively mathematics both groups above and below the group that obtained the learning of mathematics with MEAs approach is significantly better than the group of students and groups that get under ordinary learning, and improved students' mathematical thinking skills critically well below the top group and the group that learn with regular learning is significantly better than the group of students and a group under study with MEAs approach. Further analysis of students' attitudes questionnaire data showed that students showed a positive attitude towards learning mathematics with MEAs approach .

Key words : ability to think critically and creatively mathematical, approach to eliciting Model Activities (MEAs)

\section{Pendahuluan}

\section{A. Latar Belakang}

Kemampuan berpikir, baik berpikir kritis maupun berpikir kreatif merupakan kemampuan yang penting untuk dimiliki siswa agar siswa dapat memecahkan persoalan-persoalan yang dihadapi dalam dunia yang senantiasa berubah. Dengan demikian, pengembangan kemampuan berpikir, baik berpikir kritis maupun berpikir kreatif merupakan suatu hal yang penting untuk dilakukan dan perlu dilatihkan pada siswa mulai dari jenjang pendidikan dasar sampai jenjang pendidikan menengah.

Pentingnya keterampilan berpikir kritis dan kreatif dilatihkan kepada siswa, didukung oleh visi pendidikan matematika yang mempunyai dua arah pengembangan, yaitu memenuhi kebutuhan masa kini dan masa yang akan datang (Sumarmo, 2002).Visi pertama untuk kebutuhan masa kini, pembelajaran matematika mengarah pada pemahaman konsep-konsep yang diperlukan untuk menyelesaikan masalah matematika dan ilmu pengetahuan lain. Visi kedua untuk kebutuhan masa yang akan datang atau mengarah ke masa depan, mempunyai arti lebih luas, yaitu pembelajaran matematika memberikan kemampuan nalar yang logis, sistematis, kritis, dan cermat serta berpikir objektif dan terbuka, yang sangat diperlukan dalam kehidupan sehari-hari serta untuk menghadapi masa depan yang selalu berubah. 
Penyebab lain sulitnya siswa memahami pelajaran matematika adalah karena pembelajaran matematika yang mereka rasakan kurang bermakna. Masih ada guru, pada saat pembelajaran matematika tidak mengaitkan dengan kehidupan sehari-hari, padahal menurut Jenning dan Dunne (Ratnaningsih, 2007) bahwa mengaitkan pengalaman kehidupan nyata siswa dengan idea-idea matematika dalam pembelajaran di kelas penting dilakukan, agar pembelajaran bermakna.

Sebagai upaya memfasilitasi siswa agar kemampuan berpikir kritis dan kreatifnya berkembang, yaitu dengan suatu pembelajaran dimana pembelajaran tersebut harus berangkat dari pembelajaran yang membuat siswa aktif sehingga siswa leluasa untuk berpikir dan mempertanyakan kembali apa yang mereka terima dari gurunya. Hal ini dikemukakan Ibrahim (2007) bahwa untuk membawa ke arah pembelajaran yang dapat mengembangkan kemampuan berpikir kritis dan kreatif harus berangkat dari pembelajaran yang membuat siswa aktif.

Pembelajaran matematika dengan pendekatan Model-Eliciting-Activities (MEAs) merupakan suatu alternatif pendekatan yang berupaya membuat siswa dapat secara aktif terlibat dalam proses pembelajaran matematika di kelas. Keaktifan siswa itu terwujud dalam salah satu karakteristik pendekatan MEAs yaitu memberikan siswa peluang untuk mengambil kendali atas pembelajaran mereka sendiri dengan pengarahan proses (Chamberlin, 2005). Dengan terlibatnya siswa secara aktif dalam proses pembelajaran maka diharapkan kemampuan berpikir kritis dan kreatif siswa dalam matematika akan terus terlatih dengan baik.

\section{B. Rumusan Masalah}

Berdasarkan uraian di atas, masalah dalam penelitian ini adalah:

1. Apakah peningkatan kemampuan berpikir kritis matematik siswa yang memperoleh pembelajaran menggunakan pendekatan MEAs lebih baik daripada siswa yang memperoleh pembelajaran menggunakan cara biasa?

2. Apakah peningkatan kemampuan berpikir kreatif matematik siswa yang memperoleh pembelajaran menggunakan pendekatan $M E A s$ lebih baik daripada siswa yang memperoleh pembelajaran menggunakan cara biasa?

3. Apakah terdapat perbedaan peningkatan kemampuan berpikir kritis matematik siswa yang memperoleh pembelajaran menggunakan pendekatan MEAs dengan siswa yang memperoleh pembelajaran menggunakan cara biasa ditinjau dari kelompok tinggi, sedang, dan rendah?

4. Apakah terdapat perbedaan peningkatan kemampuan berpikir kreatif matematik siswa yang memperoleh pembelajaran menggunakan pendekatan $M E A s$ dengan siswa yang memperoleh pembelajaran menggunakan cara biasa ditinjau dari kelompok tinggi, sedang, dan rendah? 
5. Apakah terdapat hubungan antara kelompok siswa dengan kemampuan berpikir kritis dan kreatif matematik siswa kelas eksperimen dan kelas kontrol?

6. Bagaimanakah sikap siswa terhadap pembelajaran matematika setelah diberikan pembelajaran menggunakan pendekatan $M E A s$ ?

\section{Telaah Kepustakaan}

\section{Berpikir Kritis Matematik}

Wijaya (Ibrahim, 2007) menyatakan bahwa berpikir kritis mengarah pada kegiatan menganalisa gagasan ke arah yang lebih spesifik, membedakan sesuatu hal secara tajam, memilih, mengidentifikasi, mengkaji, dan mengembangkan ke arah yang lebih sempurna. Selanjutnya, John Chaffee (Ibrahim, 2007) mengartikan berpikir kritis sebagai berpikir yang digunakan untuk menyelidiki secara sistematis proses berpikir seseorang dalam menggunakan bukti dan logika pada proses berpikir tersebut.

\section{Berpikir Kreatif Matematik}

Berpikir kreatif merupakan kegiatan mental yang menghasilkan sesuatu yang baru hasil dari pengembangan. Hal ini sesuai dengan pendapat Coleman dan Hammen (Sukmadinata,2004a) bahwa "Berpikir kreatif adalah suatu kegiatan mental untuk meningkatkan kemurnian (originality) dan ketajaman pemahaman (insight) dalam mengembangkan sesuatu (generating)". Kemampuan berpikir kreatif berkenaan dengan kemampuan menghasilkan atau mengembangkan sesuatu yang baru, yaitu sesuatu yang tidak biasa yang berbeda dari ide-ide yang dihasilkan kebanyakan orang.

Terdapat empat tahap dalam berpikir kreatif, yaitu; (1) Exploring, mengidentifikasi hal-hal apa saja yang ingin dilakukan dalam kondisi yang ada pada saat ini; (2) Inventing, melihat atau mereview berbagai alat, teknik, dan metode yang telah dimiliki yang mungkin dapat membantu dalam menghilangkan cara berpikir yang tradisional; (3) Choosing, mengidentifikasi dan memilih ide-ide yang paling mungkin untuk dilaksanakan; (4) Implementing, bagaimana membuat suatu ide dapat diimplementasikan.

\section{Pembelajaran dengan Pendekatan MEAs}

MEAs diterapkan dalam beberapa langkah (Chamberlin, 2005), yaitu: guru membaca sebuah artikel koran yang mengembangkan konteks siswa; siswa siap dengan pertanyaan berdasarkan artikel tersebut; guru membacakan pernyataan masalah bersama siswa dan memastikan bahwa setiap kelompok mengerti apa yang sedang ditanyakan; siswa berusaha untuk menyelesaikan masalah tersebut; siswa mempresentasikan model matematis mereka setelah membahas dan meninjau ulang 
solusi; dan interpretasi siswa tentang aktivitas untuk menciptakan konstruksikonstruksi yang sesuai dengan titik pandang aktivitas tertentu.

\section{Disain dan Instrumen}

Penelitian ini adalah eksperimen dengan desain Pretes-Postest Control Group Design. Populasi penelitian ini adalah seluruh siswa pada salah satu SMA Negeri di Bandung. Selanjutnya yang menjadi sampel penelitian adalah siswa kelas X. Sampel diambil secara purposive sebanyak dua kelas dari delapan kelas yang ada di SMA ini yang mempunyai karakteristik dan kemampuan akademik setara berdasarkan pertimbangan dari guru bidang studi matematika, yaitu kelas X-A (kelas kontrol) dan kelas X-B (kelas eksperimen).

Berdasarkan jenis data yang diharapkan dalam penelitian ini, maka untuk memperoleh data digunakan tiga instrumen yaitu tes kemampuan berpikir kritis matematik, tes kemampuan berpikir kreatif matematik, dan skala sikap siswa. Untuk mendapatkan instrumen penelitian yang memenuhi alat ukur baku, maka instrumen yang telah disusun diuji cobakan terlebih dahulu dan dihitung validitas masingmasing butir soal.

\section{Teknik Analisis Data}

Data hasil tes yang diperoleh dari hasil pengumpulan data selanjutnya dianalisis melalui tahap-tahap berikut:

1. Memberikan skor jawaban siswa sesuai dengan kunci jawaban dan pedoman penskoran yang digunakan.

2. Membuat tabel skor hasil tes siswa baik pretes, postes, maupun gain ternormalisasi dari kelompok I dan kelompok II dalam kemampuan berpikir kritis dan kreatif matematik.

3. Mengelompokan siswa dalam kelompok tinggi, sedang, dan rendah baik pada kelas eksperimen maupun kelas kontrol. Pengelompokan siswa didasarkan pada pendapat Rahmat (1998) yang ditampilkan pada Tabel 3.14 berikut:

Tabel 1. Kategori Pengelompokan Siswa

keterangan:

\begin{tabular}{|c|c|}
\hline Interval & Kategori \\
\hline$X>\bar{X}_{\text {ideal }}+0,5 S_{\text {ideal }}$ & Tinggi \\
\hline $\bar{X}_{\text {ideal }}-0,5 S_{\text {ideal }} \leq X \leq \bar{X}_{\text {ideal }}+0,5 S_{\text {ideal }}$ & Sedang \\
\hline$X<\bar{X}_{\text {ideal }}-0,5 S_{\text {ideal }}$ & Rendah \\
\hline
\end{tabular}




$$
\begin{aligned}
X_{\text {ideal }} & =\text { Skor maksimal } \\
\bar{X}_{\text {ideal }} & =\frac{1}{2} X_{\text {ideal }} \\
S_{\text {ideal }} & =\frac{1}{3} \bar{X}_{\text {ideal }}
\end{aligned}
$$

4. Menghitung rerata skor tes setiap kelompok.

5. Menghitung standar deviasi untuk mengetahui penyebaran kelompok dan menunjukkan tingkat variansi kelompok data.

6. Peningkatan kemampuan berpikir kritis dan kreatif matematik yang terjadi sebelum dan sesudah pembelajaran dihitung dengan rumus gain ternormalisasi dengan rumus (Meltzer, 2002):

Gain ternormalisasi $(\mathrm{g})=\frac{\text { skorpostes }- \text { skorpretes }}{\text { skorideal }- \text { skorpretes }}$

Hasil perhitungan indeks gain kemudian diinterpretasikan dengan menggunakan kategori menurut Hake (Meltzer, 2002) yaitu:

Tabel 2. Klasifikasi Gain (g)

\begin{tabular}{|c|c|}
\hline Besarnya Gain (g) & Interpretasi \\
\hline $\mathrm{g} \geq 0,7$ & Tinggi \\
\hline $0,3 \leq \mathrm{g}<0,7$ & Sedang \\
\hline $\mathrm{g}<0,3$ & Rendah \\
\hline
\end{tabular}

7. Menguji prasyarat analisis data hasil pretes dan postes yaitu uji normalitas dan homogenitas.

8. Menguji dan menganalisis data penelitian hasil pretes dan postes dengan uji perbedaan dua rerata.

9. Menganalisis data hasil skala sikap siswa

\section{Hasil Penelitian dan Pembahasan}

\section{Kemampuan Berpikir Kritis Matematik}

Berdasarkan hasil analisis data tes awal diketahui bahwa terdapat perbedaan yang signifikan antara kemampuan awal berpikir kritis matematik siswa kelompok eksperimen dan kelompok kontrol. Karena hasil uji perbedaan rerata pretes kelas eksperimen dan kelas kontrol diperoleh terdapat perbedaan yang signifikan, maka selanjutnya untuk melihat perbedaan peningkatan kemampuan berpikir kritis matematik siswa setelah diberikan pembelajaran dilakukan uji perbedaan rerata pada data gainnya menggunakan uji-t. Sehingga dapat disimpulkan bahwa secara 
signifikan, kemampuan berpikir kritis matematik kelas kontrol lebih baik daripada kelas eksperimen. Selanjutnya, hasil menunjukan bahwa rerata peningkatan kemampuan berpikir kritis kelas eksperimen sebesar 0,29 yang artinya peningkatannya tergolong rendah, sedangkan pada kelas kontrol sebesar 0,37 yang artinya peningkatannya tergolong sedang. Selanjutnya, hasil perhitungan rerata kemampuan berpikir kritis matematik siswa eksperimen dan kontrol berdasarkan kelompok siswa.

\section{Tabel 3. Rerata Pretes, Postes, dan Gain Kemampuan Berpikir Kritis Matematik Siswa Berdasarkan Kelompok Siswa}

\begin{tabular}{|c|c|c|c|c|c|c|}
\hline \multicolumn{6}{|c|}{ Rerata Kemampuan Berpikir Kritis Matematik } \\
\hline \multirow{2}{*}{$\begin{array}{c}\text { Kel } \\
\text { Siswa }\end{array}$} & \multicolumn{2}{|c|}{ Tinggi } & \multicolumn{2}{c|}{ Sedang } & \multicolumn{2}{c|}{ Rendah } \\
\cline { 2 - 7 } & $M E A s$ & Biasa & $M E A s$ & Biasa & $M E A s$ & Biasa \\
\hline Pretes & 8,091 & 3,375 & 7,462 & 3,813 & 8,200 & 3,333 \\
\hline Postes & 24,545 & 23,750 & 20,923 & 25,813 & 23,100 & 23,500 \\
\hline Gain & 0,317 & 0,360 & 0,254 & 0,392 & 0,288 & 0,356 \\
\hline
\end{tabular}

Hasil perhitungan uji statistik diperoleh secara signifikan tidak terdapat perbedaan kemampuan berpikir kritis matematik siswa kelas kontrol ditinjau dari pasangan kelompok siswa. Sehingga, disimpulkan bahwa berdasarkan uji statistik, masingmasing pasangan kelompok siswa kelas kontrol tidak memiliki perbedaan kemampuan berpikir kritis matematik siswa.

\section{Kemampuan Berpikir Kreatif Matematik}

Berdasarkan hasil analisis data tes awal diketahui bahwa tidak terdapat perbedaan yang signifikan kemampuan awal berpikir kreatif matematik siswa antara kelompok eksperimen dengan kelompok kontrol. Karena hasil uji perbedaan rerata kemampuan awal menunjukan tidak terdapat perbedaan yang signifikan, maka uji selanjutnya untuk melihat terdapat atau tidak terdapat perbedaan kemampuan berpikir kreatif matematik siswa, dilakukan uji perbedaan rerata untuk data postesnya menggunakan uji- $t$ dan hasil menunjukkan bahwa terdapat perbedaan kemampuan berpikir kreatif matematik siswa antara kelas eksperimen dengan kelas kontrol.

Selanjutnya untuk melihat perbedaan peningkatan kemampuan berpikir kreatif matematik siswa setelah diberikan pembelajaran dilakukan uji perbedaan rerata pada data gainnya. Hasil menunjukkan bahwa kemampuan berpikir kreatif matematik 
kelas eksperimen lebih baik daripada kelas kontrol dan diketahui bahwa rerata peningkatan kelas eksperimen sebesar 0,46 yang artinya peningkatannya tergolong sedang, sedangkan kelas kontrol sebesar 0,20 yang artinya peningkatannya tergolong rendah.

Berikut disajikan hasil perhitungan rerata kemampuan berpikir kreatif matematik siswa kelas eksperimen dan kelas kontrol berdasarkan kelompok siswa.

\section{Tabel 4. Rerata Pretes, Postes, dan Gain Kemampuan Berpikir Kreatif Matematik Siswa Berdasarkan Kelompok Siswa}

\begin{tabular}{|c|c|c|c|c|c|c|}
\hline \multicolumn{6}{|c|}{ Rerata Kemampuan Berpikir Kreatif Matematik Siswa } \\
\hline Kel & \multicolumn{2}{|c|}{ Tinggi } & \multicolumn{2}{c|}{ Sedang } & \multicolumn{2}{c|}{ Rendah } \\
\cline { 2 - 7 } Siswa & $M E A s$ & Biasa & $M E A s$ & Biasa & $M E A s$ & Biasa \\
\hline Pretes & 7,636 & 6,250 & 5,538 & 7,125 & 7,850 & 6,111 \\
\hline Postes & 23,182 & 14,500 & 21,077 & 13,938 & 22,700 & 12,056 \\
\hline Gain & 0,478 & 0,242 & 0,451 & 0,207 & 0,461 & 0,174 \\
\hline
\end{tabular}

Hasil perhitungan uji statistik diperoleh secara signifikan tidak terdapat perbedaan kemampuan berpikir kreatif matematik siswa kelas kontrol ditinjau dari pasangan kelompok siswa. Sehingga, disimpulkan bahwa berdasarkan uji statistik, masingmasing pasangan kelompok siswa kelas kontrol tidak memiliki perbedaan kemampuan berpikir kreatif matematik siswa.

\section{Sikap Siswa terhadap Matematika dan Pembelajaran Matematika dengan Pendekatan MEAs}

Analisis sikap siswa terhadap matematika meliputi indikator kesukaan terhadap pelajaran matematika dan kegunaan mempelajari matematika. Dari interpretasi pernyataan tentang respon siswa terhadap pelajaran matematika diperoleh kesimpulan bahwa sebagian besar siswa mempunyai respon yang positif terhadap pelajaran matematika.

Analisis sikap siswa terhadap pembelajaran matematika dengan pendekatan $M E A s$ meliputi menunjukkan kesungguhan dalam mengikuti pelajaran matematika, penilaian tentang pembelajaran dengan pendekatan $M E A s$, dan kegunaan/manfaat dari pembelajaran dengan pendekatan MEAs. Dari interpretasi pernyataan tentang respon siswa terhadap pembelajaran matematika diperoleh kesimpulan bahwa 
sebagian besar siswa mempunyai respon yang positif terhadap pembelajaran matematika.

\section{Pembahasan}

Banyak faktor yang menyebabkan pembelajaran dengan pendekatan biasa berpengaruh lebih tinggi dan berbeda signifikan terhadap kemampuan berpikir kritis siswa dibanding dengan pembelajaran dengan pendekatan $M E A s$, antaranya yaitu dapat dikarenakan sekolah yang dipilih pada penelitian ini adalah sekolah level sedang ke bawah. Pendidikan sebagai sebuah proses belajar mengajar memang tidak cukup dengan sekedar mengejar masalah kecerdasan saja. Berbagai potensis anak didik atau subyek belajar lainnya juga harus mendapat perhatian yang proporsional agar berkembang secara optimal. Karena itulah aspek atau faktor rasa atau emosi maupun keterampilan fisik juga perlu mendapat kesempatan yang sama untuk berkembang.

Selain proses pembelajaran yang dianggap baru, pembelajaran dengan pendekatan $M E A s$ yang dirancang pada penelitian ini dibagi dalam tiga kategori yaitu "masalah realistis, kelompok kecil, dan model", yang jika ditelaah lebih lanjut pembelajaran dengan pendekatan $M E A s$ yang diberikan pada kelas eksperimen yaitu siswa dilatih menyelesaikan masalah-masalah realistis dalam bentuk model matematika secara berkelompok. Pada saat proses pembelajaran, siswa juga diajak untuk melakukan kegiatan menggambar atau mempresentasikan suatu masalah yang didiskusikannya. Hal ini sangat berpengaruh signifikan terhadap peningkatan kemampuan berpikir kreatif siswa, terutama siswa lebih "lentur" dalam menghasilkan ide-ide matematika yang beragam pada saat mengkreasikan model matematika seperti yang diharapkan pada penelitian ini,namun tidak terhadap kemampuan berpikir kritis matematik siswa.

Selanjutnya pada peningkatan kemampuan berfikir kreatif diketahui bahwa pembelajaran dengan pendekatan $M E A s$ lebih baik dari pembelajaran biasa. Hal ini dikarenakan pembelajaran menggunakan pendekatan $M E A s$ dirancang untuk melatih siswa berpikir kreatif terutama dalam pelajaran matematika khususnya materi yang diteliti pada penelitian ini. Tiap langkah pada pembelajaran menggunakan pendekatan MEAs masing-masing memberi kontribusi yang besar dalam membangun kemampuan berpikir kreatif matematik siswa, berikut uraiannya.

Pendekatan MEAs merupakan pendekatan yang didasarkan pada masalah realistis, bekerja dalam kelompok kecil, dan menyajikan sebuah model untuk membantu siswa membangun pemecahan masalah dan membuat siswa menerapkan pemahaman konsep matematika yang telah dipelajarinya. MEAs diterapkan dalam beberapa langkah, yaitu: guru mereviu materi sebelumnya untuk mengajak siswa mengingat materi sebelumnya sehingga mempermudah siswa mengikuti materi 
selanjutnya; guru kemudian memberikan lembar kerja siswa (LKS) yang telah disusun berbentuk pertanyaan-pertanyaan yang dapat menggiring siswa mengembangkan kemampuan berpikir kreatifnya; siswa bersama teman kelompoknya berdiskusi berusaha untuk menyelesaikan masalah pada LKS; guru mengawasi siswa dan memberi motivasi serta membantu siswa yang mengalami kesulitan dengan tidak langsung memberikan jawaban kepada siswa namun lebih pada memberikan kunci jawaban; kelompok siswa mempresentasikan jawaban hasil diskusinya yang berupa model matematika dan kelompok lain mengungkapkan ide dan gagasannya jika ada yang tidak sesuai menurut pendapat mereka; guru mengarahkan jawaban siswa; setelahmereka membahas semua pertanyaan pada LKS dengan presentasi selanjutnya siswa meninjau ulang solusi pertanyaan dengan arahan guru. Siswa sering berdiskusi, membuat paraphrase untuk memberi kesan pada $M E A s$, seperti membentuk model matematik yang dapat dipaparkan secara berurutan.

Berdasarkan tanggapan siswa melalui skala sikap diperoleh temuan bahwa secara umum tanggapan siswa terhadap pembelajaran matematika dengan pendekatan $M E A s$ sangat baik. Hal ini tidak terlepas dari rancangan pembelajaran dan cara guru dalam menyajikan serta mengemas pembelajaran. Sehingga pembelajaran dengan pendekatan MEA smenghasilkan tanggapan yang positif dari para siswa.

\section{Kesimpulan dan Saran}

Berdasarkan hasil analisis data dan temuan penelitian yang diperoleh di lapangan selama menerapkan pembelajaran matematika dengan menggunakan pendekatan $M E A s$, diperoleh kesimpulan sebagai berikut:

1. Peningkatan kemampuan berpikir kritis matematik siswa yang memperoleh pembelajaran dengan cara biasalebih baik dibandingkan dengan siswa yang memperoleh pembelajaran menggunakan pendekatan MEAs. Lebih lanjut, peningkatan kemampuan berpikir kritis kelas yang memperoleh pembelajaran menggunakan pendekatan MEAs tergolong rendah, sedangkan kelas yang memperoleh pembelajaran dengan cara biasapeningkatan kemampuan berpikir kritisnya tergolong sedang.

2. Peningkatan kemampuan berpikir kreatif matematik siswa yang memperoleh pembelajaran menggunakan pendekatan MEAslebih baik dibandingkan dengan siswa yang memperoleh pembelajaran dengan cara biasa.Lebih lanjut, peningkatan kemampuan berpikir kreatif kelas yang memperoleh pembelajaran menggunakan pendekatan MEAs tergolong sedang, sedangkan kelas yang memperoleh pembelajaran dengan cara biasa peningkatan kemampuan berpikir kreatifnya tergolong rendah.

3. Tidak terdapat perbedaan yang signifikan antara kemampuan berpikir kritis matematik siswa kelas eksperimen ditinjau dari kelompok siswa. Pada kelas eksperimen, baik pada pasangan kelompok tinggi dan sedang, tinggi dan rendah, 
maupun sedang dan rendah, tidak terdapat perbedaan yang signifian kemampuan berpikir kritisnya.

4. Tidak terdapat perbedaan yang signifikan antara kemampuan berpikir kritis matematik siswa kelas kontrol ditinjau dari kelompok siswa. Pada kelas kontrol, baik pada pasangan kelompok tinggi dan sedang, tinggi dan rendah, maupun sedang dan rendah, tidak terdapat perbedaan yang signifian kemampuan berpikir kritisnya.

5. Tidak terdapat perbedaan yang signifikan antara kemampuan berpikir kreatif matematik siswa kelas eksperimen ditinjau dari kelompok siswa. Pada kelas eksperimen, baik pada pasangan kelompok tinggi dan sedang, tinggi dan rendah, maupun sedang dan rendah, tidak terdapat perbedaan yang signifian kemampuan berpikir kreatifnya.

6. Tidak rerdapat perbedaan yang signifikan antara kemampuan berpikir kreatif matematik siswa kelas kontrol ditinjau dari kelompok siswa. Pada kelas kontrol, baik pada pasangan kelompok tinggi dan sedang, tinggi dan rendah, maupun sedang dan rendah, tidak terdapat perbedaan yang signifian kemampuan berpikir kreatifnya.

7. Tidak terdapat hubungan antara kelompok siswa dengan kemampuan berpikir kritis dan kreatif matematik pada siswa kelas eksperimen dan kelas kontrol.

8. Jika ditinjau secara keseluruhan, siswa memberikan sikap yang positif terhadap pembelajaran matematika dengan pendekatan $M E A s$.

Melihat hasil temuan dalam penelitian ini, saran-saran yang diajukan oleh penulis adalah:

1. Pembelajaran dengan pendekatan $M E A s$ dapat dijadikan salah satu alternatif pembelajaran untuk meningkatkan kemampuan berpikir kreatif matematik.

2. Untuk penelitian selanjutnya dapat meneliti kemampuan berpikir kritis matematik siswa dan kemampuan berpikir kreatif matematik siswa dengan pendekatan MEAs pada level sekolah yang berbeda.

3. Penelitian selanjutnya dapat meneliti lebih lanjut kemampuan berpikir kritis matematik siswa dan kemampuan berpikir kreatif matematik siswa dengan pendekatan MEAs ditinjau dari level sekolah (level tinggi, sedang, dan rendah).

4. Penelitian selanjutnya dapat menggunakan model pembelajaran $M E A s$ dijenjang pendidikan yang berbeda.

5. Penelitian selanjutnya dapat menggunakan pembelajaran dengan pendekatan MEAs pada materi yang berbeda, namun disarankan agar memilih materi yang banyak aplikasinya dalam kehidupan nyata.

\section{DAFTAR PUSTAKA}

Chamberlin, S. A., Moon, S. M. (2005). How Does the Problem Based Learning Approach Compare to the Model-Eliciting Activity Approach in Mathematics? (http://www.cimt.plymouth.ac.uk/journal/chamberlin.pdf). 
Ibrahim (2007). Pengembangan Kemampuan Berpikir Kritis dan Kreatif Siswa SMP dalam Matematika melalui Pendekatan Advokasi dengan Penyajian Masalah Open-Ended. Tesis Sekolah Pasca Sarjana UPI. Bandung: Tidak dipublikasikan.

Meltzer, D.E. (2002). The Relationship between Mathematics Preparation and Conceptual Learning Gain in Physics: A Possible "Hidden Variable" in Diagnostics Pretest Scores. Dalam American Journal of Physics. Vol. 70 (12) 1259-1268. [Online]. Tersedia: http.//www.physics. iastate.edu/per/docs/Addendum_on_normalized_gain. [9 Oktober 2006].

Rahmat (1998). Statistika untuk Lembaga \& Instansi Pemerintah. Bandung:PPPLPTK

Ratnaningsih, N. (2007). Pengaruh Pembelajaran Konstekstual terhadap Kemampuan Berpikir Kritis dan Kreatif Matematika Siswa Sekolah Menengah Atas. Disertasi Sekolah Pasca Sarjana UPI. Bandung: Tidak dipublikasikan.

Sukmadinata, N.S. (2004). Kurikulum dan Pembelajaran Kompetensi. Bandung: Yayasan Kesuma Karya.(a).

Sumarmo, U. (2002). Alternatif Pembelajaran Matematika untuk Mendukung Pelaksanaan Kurikulum Berbasis Kompetensi. Makalah pada Seminar Tingkat Nasional FPMIPA UPI. Banung: Tidak dipublikasikan. 